\title{
B19 Avaliação da expressão gênica de citocinas e polimorfismo da IL-28B em voluntários sadios após administração de IFN $\alpha$ peguilhado
}

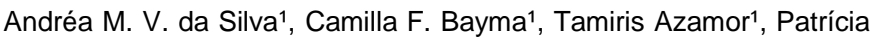
Cristina C. Neves ${ }^{1}$, Ana Carolina M. Andrade ${ }^{1}$, Lucia Elena Alvarado A. $^{2}$, Alexandre S. de Almeida ${ }^{2}$, Marcelo R. Alves ${ }^{3}$, Eliane M. dos Santos ${ }^{1}$, Milton O. Moraes ${ }^{2}$, Denise Cristina de S. Matos ${ }^{1}$

1 Bio-Manguinhos, Fiocruz, Rio de Janeiro, RJ

2 IOC, Fiocruz, Rio de Janeiro, RJ

${ }^{3}$ IPEC, Fiocruz, Rio de Janeiro, RJ

Introdução: $\mathrm{O}$ vírus de hepatite $\mathrm{C}$ (HCV) é um dos principais causadores de doença crônica no fígado, levando muitos casos progredirem para cirrose/hepatocarcinoma. Estudos demostram que diferenças genéticas podem ter impacto na resposta imunológica ao tratamento. Polimorfismos de base única (SNP) no gene da IL28-B atuam como fatores preditivos na resposta ao tratamento com interferon alfa (IFN- $\alpha$ ), a despeito do genótipo do vírus que infecta o hospedeiro. O IFN- $\alpha$ age na indução de centenas de genes que estabelecem um estado antiviral inespecífico ao vírus dentro da célula. Entretanto, o mecanismo da função antiviral do IFN- $\alpha$ bem como papel dos SNPs de IL-28B ainda não está completamente elucidado.

Objetivos: Avaliar a expressão gênica de citocinas e sua relação com o polimorfismo da IL-28B, em voluntários sadios, após administração de uma dose de IFN-PEG (A ou B), buscando identificar assinaturas gênicas/ fatores genéticos que possam ser correlacionados a cada um dos tratamentos.

Metodologia: Foram avaliados 18 voluntários, nos tempos $0,12,24$, 48 e 72 horas após administração do tratamento A ou B (CONEP 2530.214576/2011-44). Foi avaliada a expressão de 89 genes de citocinas utilizando qPCR multiplex no sistema BioMark HD®. Para a detecção de polimorfismos foram avaliados 7 SNPs (IL-28B) por qPCR com o auxilio de sondas TaqMan, equipamento StepOne Plus (Life Technologies).

Resultados: Foi observado um aumento na expressão de genes estimulados pela via de interferon (ISGs - IFN stimulated genes), destacando os genes que codificam a OAS 1 e 3, ISG15, e outros como RIG-1, STAT-2, TICAM-1 e IRF9, que estão diretamente relacionados à produção de proteínas que induzem o bloqueio da transcrição e degradação do RNA viral, inibindo a tradução ou interferindo com várias etapas da replicação do vírus. Houve uma diferença no perfil de expressão desses genes, ao longo da cinética, entre os tratamentos, privilegiando o tratamento $B$. A expressão gênica também foi analisada, estratificando-se os indivíduos em função dos genótipos do 
SNP rs12979860 (CC associada com RVS, e genótipos CT e TT associados a falha terapêutica). Os resultados demonstraram uma associação do genótipo CC com o aumento da expressão gênica de moléculas como OAS1 e OAS2. Além disto, a análise de haplótipos $\left(r^{2}-\right.$ programa Haploview) identificou que os SNPs rs12979860 encontram-se em forte desequilíbrio de ligação (DL) com rs4803217( $r 2=0,84)$, e ainda, o rs8099917 apresentou valor de $r^{2}=1$ com rs8105790.

Conclusão: Estes resultados indicam que há influência genética na expressão de citocinas/quimiocinas observada após os tratamentos, com indivíduos do genótipo CC (SNP rs12979860) apresentando aumento da expressão de genes destas moléculas em comparação com indivíduos dos genótipos CT e TT. Além disto, as análises de DL sugerem que outros SNPs podem também estar relacionados com o desfecho do tratamento. Além desses fatores genéticos, também observou-se que a expressão de alguns dos genes estudados podem ser influenciada pelo tratamento administrado.

Palavras-Chaves: Interferon Peguilado, Citocinas, IL-28B 